\title{
Factor Analysis of Knowledge Level and Cultural Background on Health Care for Hypertension Patients in Bengkalis Regency in 2021
}

\author{
Nur Azmi ${ }^{1}$, Lita Sri Andayani ${ }^{2}$, R. Kintoko Rochadi ${ }^{3}$ \\ ${ }^{1,2,3}$ Universitas Sumatera Utara, Indonesia \\ Corresponding Author: Nur Azmi
}

\begin{abstract}
Hypertension is a degenerative disease that greatly affects a person's productivity and quality of life, is a silent killer with the highest prevalence rate in Indonesia. Untreated hypertension will cause complications. This study aims to determine the level of knowledge and cultural background factors on the health maintenance of hypertension patients in Bengkalis Regency in 2021. This type of research is quantitative analytic with a cross sectional design. The total population in this study was 5,938 with a total sample of 101 obtained using purposive sampling. The instrument in this study used a questionnaire used in the form of a Google form. The data obtained in this study were analyzed by bivariate analysis. The results showed that there was no correlation between knowledge level factors $(\mathrm{p}=0.828)$ and cultural background factors $(p=0.001)$ on health care for hypertension sufferers and the most dominant cultural background factors related to health care for hypertension sufferers $(\mathrm{p}=0.001)$.
\end{abstract}

Keywords: Knowledge Level, Cultural

Background, Health Care, Hypertension

\section{INTRODUCTION}

Changes in people's lifestyles due to urbanization, globalization, and modernization have triggered the transition of disease epidemiology. The epidemiological transition of disease is indicated by a change in disease patterns, namely the proportion of infectious diseases has decreased, but the proportion of non- communicable diseases has increased (Yarmaliza and Zakiyuddin, 2019).

The World Health Organization (WHO) states that around $71 \%$ of the causes of death in the world are non-communicable diseases (NCDs) which kill 36 million people per year (Sogno et al., 2020). WHO data shows that in 2030 it is predicted that there will be 52 million deaths per year due to non-communicable diseases. More than $40 \%$ of deaths from non-communicable diseases (NCDs) occur before the age of 70 years (Ediriweera et al., 2018). Mortality from non-communicable diseases (NCD) is expected to continue to increase, and the largest increase is in middle and low-income countries (Ganju et al., 2020).

Hypertension is a degenerative disease that greatly affects a person's productivity and quality of life, is a silent killer with the highest prevalence rate in Indonesia (Machmud, 2020). Hypertension is a condition where there is a disturbance in the circulatory system so that blood pressure rises above the normal limit, namely systolic blood pressure of $130-139 \mathrm{mmHg}$ and diastolic blood pressure of $80-89 \mathrm{mmHg}$ (Aleyadeh et al, 2019).

Silent killer with the highest prevalence rate in Indonesia. Untreated hypertension will cause complications. Most people with hypertension are not aware, they feel healthy and energetic even though their blood pressure is far above the normal limit (have hypertension), so that hypertension is often found incidentally 
when patients come to health services for examinations for reasons of certain diseases. This situation is certainly very dangerous, because it can cause delays in getting treatment which can lead to complications.

According to Efendi and Larasati (2017) family knowledge of a disease is very important. Good family knowledge of a disease allows families to know when families should seek treatment and support adherence to treatment (Sumantra et al., 2017).

One of the areas with the highest number of hypertension and increasing every year is Bengkalis Regency. Bengkalis Regency is an archipelago, most of the people work as fishermen and farmers. People who work as fishermen make part of the catch processed into salted fish. In Bengkalis Regency, salted fish is a favorite food menu for most people, besides the price is affordable compared to the price of fresh fish. In addition, people who work as farmers, after returning from work they spend more time watching TV and playing games. This is what makes hypertension increase every year.

This study aims to determine the level of knowledge and cultural background factors on the health maintenance of hypertension patients in Bengkalis Regency in 2021.

\section{RESEARCH METHODS}

This type of research is quantitative analytic with a cross sectional design, that is, the researcher makes an assessment or measurement of the independent variable and the dependent variable at one time (Nursalam, 2008).

The total population in this study was 5,938 with a total sample of 101 obtained using purposive sampling.

The instrument in this study used a questionnaire used in the form of a Google form.

The data obtained in this study were analyzed by bivariate analysis.

\section{RESULT \\ Description of Research Site}

This research was conducted in Bengkalis District, Bengkalis Regency, Riau Province. Bengkalis Regency consists of islands and land and has coastal and marine areas with a line length of $+446 \mathrm{~km}$. The location of Bengkalis Regency is very strategic, it is on the edge of international shipping lanes, namely the Malacca Strait and is in the economic growth triangle area of Indonesia, Malaysia, Singapore (IMSGT) and the economic growth triangle area of Indonesia, Malaysia, Thailand (IMT-GT). The area of Bengkalis Regency is 7,773.93 $\mathrm{km}^{2}$ divided into nine sub-districts, namely, Bengkalis District, Bantan District, Bukit Batu District, Siak Kecil District, Rupat District, North Rupat District, Mandau District, and Pinggir District. The population of Bengkalis Regency is 573,003 people (Badan Pusat Statistik, 2020).

Bengkalis sub-district has a population of 82,111 people with 41,694 men and 40,417 women. The area of Bengkalis District is $464.89 \mathrm{~km}^{2}$ divided into 31 villages namely, Sekodi village, Kelamantan, Ketamputih, Pematang Duku, Penebal, Temeran, Penampi, Sungai Alam, Air Putih, Senggoro, Rimba Sekampung, Bengkalis City, Wonosari, Damon, Kelapapati, Pedekik, Pangkalan Batang, Sebauk, Teluk Latak, Meskom, Palkun, West Kelamantan, Batang River, Pematang Duku Timur, Damai, Kelebuk, Kuala Alam, Pangkalan Batang, Sederak, Perapat Tunggal, and Simpang Ayam (Badan Pusat Statistik, 2020).

Based on data from the Central Bureau of Statistics of Bengkalis Regency, the work of the community is recorded at around $44.84 \%$ of people with residents who work as laborers, employees, and employees. The population who work in the self-employed sector is $16.61 \%$, temporary workers are $14.29 \%$, permanent workers are $1.87 \%$, freelancers/others are $8.82 \%$, and family workers are $3.11 \%$ (Badan Pusat Statistik, 2020). 


\section{Characteristics of Respondents}

Respondents in this study amounted to 101 people. Characteristics of respondents in this study were age, gender, occupation, education level, and income level. Based on the distribution of respondents' age, gender, occupation, education level, and income level, information was obtained that the distribution of respondents with the largest age group was the early adult age group (2635 years), which was 33.7 percent. The distribution of respondents with the highest gender, namely female sex as much as 54.5 percent. Respondents with the most occupational groups were other occupations as much as 47.5 percent. Respondents with the highest level of education, namely the high school education level as much as 36.6 percent, and the characteristics of the income level of the most respondents were respondents who had an income level below the minimum wage as much as 81.2 percent.

The distribution of respondents who have family members with hypertension is 100.0 percent. Respondents who live in the same house with hypertension sufferers are 100.0 percent. The distribution of family members who suffer the most from hypertension is the mother as much as 33.7 percent. The distribution of the last blood pressure to check for hypertension patients was blood pressure above $140 / 90 \mathrm{mmHg}$ as much as 69.3 percent. The distribution of places for hypertension sufferers who seek treatment at the puskesmas is 77.2 percent. Distribution of patient treatment time for blood pressure control less than once a month is 51.5 percent. The distribution of hypertension patients who took hypertension drugs was 94.1 percent. The distribution of the name of the drug that is often consumed by patients with hypertension is the most widely consumed by patients with captropil as much as 61.4 percent, and the distribution of patients who are obedient in taking drugs as much as $\mathbf{5 8 . 4}$ percent.

\section{Bivariate Analysis}

The results of bivariate analysis were used to determine the relationship between each independent variable, namely the level of knowledge and cultural background with the dependent variable, namely family support in maintaining the health of hypertension sufferers. Bivariate analysis was carried out using the chi-square test with significant or significant criteria if $\mathrm{p}<0.05$.

Table 1: Bivariate Analysis of Knowledge Level

\begin{tabular}{|c|c|c|c|c|c|c|c|}
\hline \multirow[t]{3}{*}{ Variable } & \multicolumn{6}{|c|}{ Family Support } & \multirow{3}{*}{$\begin{array}{c}\text { p. } \\
\text { Value }\end{array}$} \\
\hline & \multicolumn{2}{|c|}{ Good } & \multicolumn{2}{|c|}{ Less } & \multicolumn{2}{|c|}{ Total } & \\
\hline & $\mathbf{n}$ & $\%$ & $\mathbf{n}$ & $\%$ & $\mathbf{n}$ & $\%$ & \\
\hline $\begin{array}{l}\text { Knowledge } \\
\text { Level }\end{array}$ & & & & & & & \\
\hline Good & 31 & 47.0 & 35 & 53.0 & 66 & 100 & 0.828 \\
\hline Less & 18 & 51.4 & 17 & 48.6 & 35 & 100 & \\
\hline
\end{tabular}

Table 2: Bivariate Analysis of Cultural Background

\begin{tabular}{|l|c|c|c|c|c|c|c|}
\hline \multicolumn{7}{|c|}{ Variable } & \multicolumn{7}{c|}{ Family Support } & p. \\
\hline & \multicolumn{2}{|c|}{ Good } & \multicolumn{2}{c|}{ Less } & \multicolumn{2}{c|}{ Total } & Value \\
\hline & $\mathbf{n}$ & $\%$ & $\mathbf{n}$ & $\%$ & $\mathbf{n}$ & $\%$ & \\
\hline $\begin{array}{l}\text { Cultural } \\
\text { Background }\end{array}$ & & & & & & & \\
\hline Good & 21 & 34.4 & 40 & 65.6 & 61 & 100 & 0.001 \\
\hline Less & 28 & 70.0 & 12 & 30.0 & 40 & 100 & \\
\hline
\end{tabular}

The results showed that there was no correlation between knowledge level factors $(\mathrm{p}=0.828)$ and cultural background factors $(\mathrm{p}=0.001)$ on health care for hypertension sufferers and the most dominant cultural background factors related to health care for hypertension sufferers $(\mathrm{p}=0.001)$.

\section{CONCLUSION AND SUGGESTION}

The results showed that there was no correlation between knowledge level factors $(p=0.828)$ and cultural background factors $(\mathrm{p}=0.001)$ on health care for hypertension sufferers and the most dominant cultural background factors related to health care for hypertension sufferers $(\mathrm{p}=0.001)$.

From the results of previous research, the suggestions that can be submitted are:

1. To the Community Health Center (Puskesmas) to conduct counseling and activities for the Integrated Development Post (Posbindu) not only to involve people with hypertension, but also to involve their family members, as well as to provide counseling about the 
importance of family support in preventing hypertension.

2. The family is expected to always provide support to family members who suffer from illness, especially hypertension, because the support provided will motivate patients to maintain health.

\section{Acknowledgement: None}

\section{Conflict of Interest: None}

\section{Source of Funding: None}

\section{REFERENCES}

1. Aleyadeh, W., Centeno, E. H., Ahmed, H. M., \& Shah, N. P. (2019). Hypertension guidelines: treat patients, not numbers. Cleveland Clinic Journal, 86(1). DOI: 10.3949/ccjm.86a.18027.

2. Badan Pusat Statistik. (2020). Kabupaten Bengkalis pada Angka 2020. Badan Pusat Statistik Kabupaten Bengkalis.

3. Ediriweera, D. S., Karunapema, P., Pathmeswaran., \& Arnold, M. (2018). Increase in premature mortality due to noncommunicable diseases in Sri Lanka during the first decade of the twenty-first century. BMC Public Health, 1-6. Accessed from https://link.springer.com/article/10.1186/s12 889-018-5503-9.

4. Efendi, H., \& Larasati, T. (2017). Dukungan keluarga dalam manajemen penyakit hipertensi. 6(1). Accessed from http://juke.kedokteran.unila.ac.id/index.php/ majority/article/download/1527/1485.

5. Ganju, A., Goulart, A. C., Ray, A., Majumdar, A., Jeffers, B. W., Liamosa, G., \& Canizares, H. (2020). Systemic solutions for addressing non-communicable disease in low-and middle-income countries. Journal of Multidisciplinary Healthcare, 693-707. Accessed from https://www.ncbi.nlm.nih.gov/pmc/articles/ PMC7394587/pdf/jmdh-13-693.pdf.

6. Machmud, A. N. (2020). Hipertensi: faktor determinan hipertensi pasien rawat jalan. Jurnal Fenomena Kesehatan, 3(1), 365-377.

7. Nursalam. (2008). Konsep dan Penerapan Metodologi Penelitian Ilmu Keperawatan. Jakarta: Salemba Medika.

8. Sogno, P., Hoffmann, C. T., \& Kuenzer, C. (2020). Eart observation data supporting non-communicable disease research: a review. Journal MDPI, 1-34. Accessed from https://

www.mdpi.com/journal/remotesensing.

9. Sumantra, I. G., Kumaat, L. T., \& Bawotong, J. (2017). Hubungan dukungan informatif dan emosional keluarga dengan kepatuhan minum obat pada lansia hipertensi di puskesmas ranomuut kota manado. E-Jurnal Keperawatan, 5(1). Accessed from https://ejournal.unsrat.ac.id/index.php/jkp/ar ticle/view/14709.

10. Yarmaliza., \& Zakiyuddin. (2019). Pencegahan dini terhadap penyakit tidak menular (PTM) melalui germas. Jurnal Pengabdian Masyarakat Multidisiplin, 3(2). Accessed from https://media.neliti.com/media/publications/ 317872-pencegahan-dini-terhadap-penyakittidak-3a78b22f.pdf.

How to cite this article: Azmi N, Andayani LS, R. Kintoko Rochadi. Factor analysis of knowledge level and cultural background on health care for hypertension patients in Bengkalis Regency in 2021. International Journal of Science \& Healthcare Research. 2021; 6(3): 197-200. DOI: https://doi.org/ 10.52403/ijshr.20210733 